\title{
ESTUDO GEOESTATISTICO DA JAZIDA DE COBRE DE CHAPADA, GO
}

\author{
J.K. Yamamoto
}

PALAVRAS-CHAVE: krigagem ordinária, geoestatistica, avaliação de reservas.

YAMAMOTO, JK. (1994) Estudo geoestatístico da jazida de cobre de Chapada, GO. Bol.IG-USP. Sér.Cient., 25:29-52.

\section{RESUMO}

Este trabalho apresenta os resultados da análise geoestatistica realizada sobre os teores de cobre e ouro do Depósito da Chapada, visando a modelagem de variogramas para avaliação de reservas, por meio da técnica de krigagem ordinária.

Para atingir esse objetivo os teores de cobre e ouro das amostras dos furos de sondagem foram compostos para bancadas de $10 \mathrm{~m}$ de altura, os quais foram utilizados inicialmente para desenho dos mapas de isoteores por bancada. Com os dados compostos foram calculados os variogramas horizontais e verticais médios, que foram ajustados pelo modelo esférico. Os modelos assim obtidos foram entāo utilizados para a avaliaçāo dos blocos de cubagem, de dimensōes compativeis com a densidade de amostragem, por meio da krigagem ordinária.

\section{ABSTRACT}

Geostatistical analysis was performed on copper and gold assays of Chapada Deposit, aiming at modeling variograms for ore reserve estimation, by means of the ordinary kriging technique.

The copper and gold assays from drill hole samples were composed for $10 \mathrm{~m}$ benches and the composed samples were used to make contour maps of copper and gold concentrations for each bench. With the composed samples average horizontal and vertical variograms were computed, which fitted with the spherical model. The resulting models were applied to perform ore reserve estimation, in blocks of dimensions consistent with the available information, using the ordinary kriging technique.

\section{INTRODUÇÃO}

O estudo geoestatístico precede a fase de avaliação de reservas e tem por objetivo a determinação do modelo de variograma que descreve a variabilidade espacial das variáveis de interesse dentro do depósito mineral. Apresenta-se como estudo de caso a Jazida de Cobre de
Chapada, onde dispõem-se de mais de 10.000 determinações para cobre e em igual número para ouro, portanto, suficientes para a finalidade proposta, pois como o variograma é uma informação essencialmente estatística, quanto maior o número de dados e quanto melhor a

Departamento de Geologia Econônica e Geofisica Aplicada, Instituto de Geociências/USP, São Paulo, Brasil. 
localização dos mesmos no depósito, maior a representatividade do modelo obtido.

Como se mostra no trabalho, a análise da distribuição espacial dos dados é muito importante na interpretação dos variogramas parciais, que facilitará a obtenção e modelagem do variograma médio do depósito, como foi demonstrado na tese de doutoramento do autor (Yamamoto, 1991), que se apresenta a seguir.

\section{JAZIDA DE COBRE DE CHAPADA}

A jazida de cobre de Chapada resultou de uma pesquisa mineral, realizada pela Mineração Serras do Leste Ltda, para cobre em uma área de 4.000 ha, situada próxima à localidade de Chapada, Município e Comarca de Mara Rosa, GO. Esta área foi objeto de pesquisa após trabalhos de prospecção geoquími- ca regional realizada em sedimentos de corrente, que detectaram anomalias de cobre, as quais detalhadas resultaram na área citada. Nesta área foram continuados os trabalhos de prospecção que delimitaram uma zona com fortes anomalias de cobre, segundo direção geral NESW, com cerca de $7 \mathrm{~km}$ de extensão e largura média de aproximadamente 0,4 $\mathrm{km}$. Esta zona foi então pesquisada para cobre e ouro, cujos dados de teor, bem como as informações de interesse da jazida, foram compilados do Relatório Final de Pesquisa (Silva, 1979).

\section{LOCALIZAÇÃO E ACESSOS}

A Jazida de Cobre de Chapada localiza-se a sudoeste do povoado homônimo, Município e Comarca de Mara Rosa, Estado de Goiás, conforme o mapa de localização mostrado no desenho da Figura 1. A área estudada de 4.000

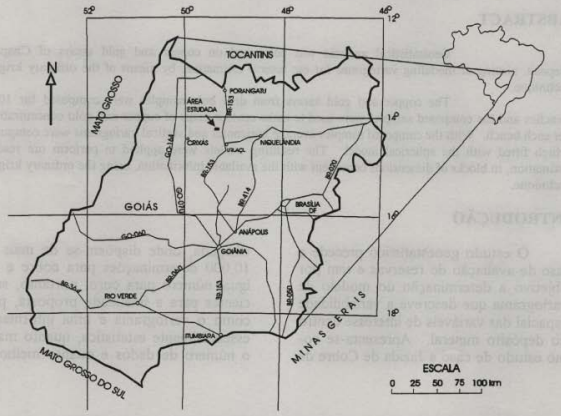

Figura 1 - Mapa de localizaçāo da Jazida de Cobre de Chapada. 
ha está delimitada pelas coordenadas geográficas $14^{\circ} 13^{\prime} 17^{\prime \prime}$ e $14^{\circ} 15^{\prime} 05^{\prime \prime}$ de latitude sul e $49^{\circ} 20^{\prime} 00^{\prime \prime}$ e $49^{\circ} 24^{\prime} 28^{\prime \prime}$ de longitude oeste.

$\mathrm{O}$ acesso à área pode ser feito por rodovia, saindo-se de Goiânia pela rodovia GO-080 até o entroncamento com a BR-153 (Belém-Brasilia), tomando-se então esta até a cidade de Campinorte e daí seguindo-se por via secundária não pavimentada por $28 \mathrm{~km}$, ou por via aérea até Uruaçu, de onde continua-se 0 percurso pela BR-153 até Campinorte.

\section{GEOLOGIA DA JAZIDA}

A Jazida de Cobre de Chapada, segundo Silva \& Sá (1988), encontra-se inserido em um pacote de rochas metamórficas pertencentes à Sequência Mara Rosa, de caráter vulcano-sedimentar.

Segundo IPT (1980a), as rochas predominantes na área em questão formam um complexo metamórfico envolvendo uma pequena intrusão sintectônica quartzo-dioritica alojada em metamorfitos. Estas correspondem essencialmente a mesclas variadas de quartzo, biotita, muscovita, anfibólio, plagioclásio e cianita, com texturas que vão de granoblástica a lepidoblástica ou nematoblásticas (com ou sem porfiroblastos), formando xistos, quartzitos, gnaisses e anfibolitos com gradaçōes entre si. Esse complexo metamórfico sujeitou-se a anatexia incipiente, que responde por veios e bolsões quartzo-feldspáticos e ocasionais zonas feldspatizadas.

A mineralização constitui-se fundamentalmente de calcopirita associada a pirita (sulfeto mais abundante), que ocorrem como finos cristais disseminados em micaxistos, principalmente biotita xisto feldspático, com matriz silicosa de granulação fina a média (Silva, 1979). "Os sulfetos apresentam caracteristicas texturais que se relacionam em grande parte com a textura da rocha hospedeira. Assim, calcopiritas eqüidi- mensionais encontram-se preferencialmente em ganga de textura granoblástica, como as rochas da unidade quartzitos; por outro lado, aquelas de forma alongada geralmente associam-se a minerais micáceos, em rochas de textura lepidoblástica a granolepidoblástica, comuns nas unidades micaxistos e anfibólio-xistos. Desse modo, as zonas de maior, incidencia de quartzitos devem corresponder aproximadamente às zonas de maior incidência de sulfetos com características texturais eqüidimensionais (especialmente calcopirita)." (In IPT, 1980b).

A estrutura predominante na jazida é um amplo e suave anticlinório de eixo NE-SW, ligeiramente complicado por ondulações de eixos NW-SE, resultante de uma evolução deformacional polifásica com três ou quatro fases de dobramentos superpostos, desenvolvendo-se familias de juntas e de pequenas falhas (IPT, 1981).

Quanto à gênese da jazida, Silva \& Sá (1988) sugerem origem vulcanogênica com possibilidade de remobilização durante a fase de cisalhamento posterior. Segundo Richardson et al. (1986), a jazida de Chapada representa o remanescente de um depósito de cobre porfiritico, onde a maior parte da mineralização foi hospedada pela rocha encaixante. Ainda segundo estes autores, a feição mais óbvia em termos de um modelo para a mineralização de Chapada é o seu teor e tonelagem, que estão perfeitamente compatíveis com depósitos de cobre porfiritico de arcos de ilhas. Um modelo alternativo ao desses autores, sugerido por Kuyumijian (1990), é o modelo singenético hidrotermal/exalativo, que baseado no fato dos sulfetos ocorrerem, freqüenternente, deformados e comumente aparecerem como inclusões em minerais metamórficos, leva-o a concluir que a mineralização que deu origem ao depósito de Chapada é prémetamórfica. 
INVENTÁRIO DA PESQUISA MINERAL

O depósito de Chapada foi extensivamente pesquisado com o objetivo da extração econômica para cobre; entretanto, com a possibilidade da presença de ouro associado aos sulfetos, verificada no decorrer dos trabalhos, a pesquisa foi também estendida para ouro.

0 inventário da pesquisa mineral da Jazida de Chapada foi feito observando-se os parâmetros recomendados por Handley et al. (1987), com o objetivo de aferir a qualidade e quantidade de informações disponiveis para fins de avaliação de reservas $e$ aos estudos propostos neste trabalho:

- densidade de dados: malha de sondagem rotativa a diamante $100 \mathrm{x}$ $50 \mathrm{~m}$ na porção central da jazida, com 11.599 amostras analisadas para cobre e 9.087 amostras analisadas para ouro;

- exatidão da localização dos pontos de dados: localização dos furos de sondagem controlada por levantamento plani-altimétrico à escala 1:2000. Quanto a possiveis desvios nos furos verticais, IPT (1980b) constatou que os ângulos de desvio aparente nos furos são menores que $5^{\circ} \mathrm{e}$, portanto, podem ser considerados verticais sem problemas à interpretação e localização de dados;

- técnica de sondagem: sondagem rotativa a diamante;

- técnica de amostragem: testemunhagem contínua em rocha, bitola $\mathrm{Nx}$ no início dos furos, reduzida para $\mathrm{Bx}$ até o fim do furo, com amostras coletadas em testemunhos serrados ao meio com serra diamantada e partidos $\mathrm{em}$ intervalos variáveis entre 1 e $2 \mathrm{~m}$, dependendo da mineralização observada no campo;

- recuperação dos testemunhos de sondagem: os dados de recuperação obtidos, revelam valores médios em torno de $95 \%$;

- densidade ou fator tonelagem: foram analisadas 66 amostras represen- tativas de tipos litológicos e variados graus de mineralização resultando em densidade aparente média, para as rochas de Chapada, igual a $2,72 \mathrm{t} / \mathrm{m}^{3}$; - qualidade das análises: cobre analisado por absorção atômica após solubilização total da amostra com ácido perclórico e ouro analisado por absorção atômica em solução metil-isobutil-cetona após solubilização da amostra com água régia. As análises de cobre, em sua maioria efetuadas pelo Laboratório de Geoquímica do IPT e sistematicamente aferidas por outros laboratórios, revelaram-se confiáveis para os fins do objetivo da pesquisa;

- recuperação do beneficiamento: não existem problemas de recuperação no beneficiamento, pois segundo Silva \& Sá (1988), ensaios de bancada revelaram uma recuperação de pelo menos $90 \%$ do cobre contido, tendo-se verificado um bom desempenho às técnicas de tratamento convencionais.

Foram executados no Projeto Chapada 156 furos de sondagem rotativa a diamante, conforme o mapa geral de distribuição dos furos de sondagem da Figura 2. Nesta figura, encontra-se delimitada a área de interesse da jazida entre as coordenadas leste 750 e $3250 \mathrm{~m}$ e entre as coordenadas norte -650 e $250 \mathrm{~m}$. Dentro desta área de interesse encontram-se 142 furos de sondagem, que serão efetivamente utilizados no presente trabalho.

\section{COMPOSIÇĀO DE AMOSTRAS DE FUROS DE SONDAGEM}

Como a futura lavra será a céu aberto pelo método tradicional de bancadas, a composição de amostras de furos de sondagem deverá ser feita para um intervalo de trabalho igual à altura das bancadas $(10 \mathrm{~m})$.

Dentro da área de interesse da jazida encontram-se 142 furos de sondagem, que totalizaram 10.829 amostras, 


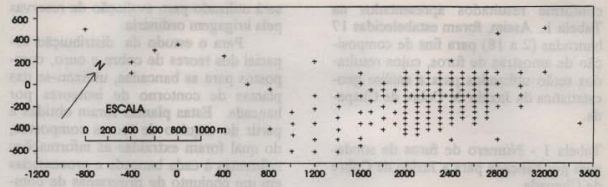

Figura 2 - Mapa geral de distribuição dos furos de sondagem.

das quais 10.504 analisadas para cobre e 9.029 para ouro. As bancadas foram estabelecidas após análise dos mapas de elevações (Figs. 3 e 4) da área de inte- resse e da incidência dos furos de sondagem na mesma, calculando-se para cada bancada de $10 \mathrm{~m}$ de altura o número de furos de sondagem que a atravessavam,

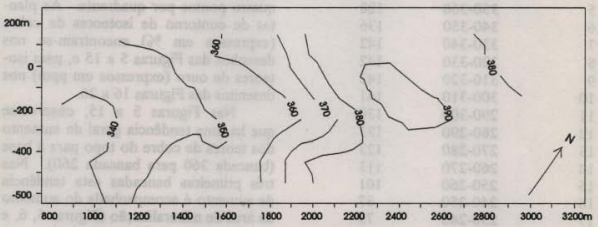

Figura 3 - Mapa de elevaçōes da superficie da área de interesse.

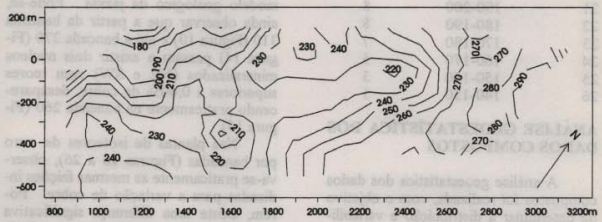

Figura 4 - Mapa de elevaçóes da base da área de interesse. 
conforme resultados apresentados na Tabela 1. Assim, foram estabelecidas 17 bancadas (2 a 18) para fins de composição de amostras de furos, cujos resultados serão utilizados para a análise geoestatistica da Jazida de Cobre de Chapada.

Tabela 1 - Número de furos de sondagem por bancada para a Jazida de Cobre de Chapada.

$\begin{array}{lcc}\text { Bancada } & \text { Cotas }(\mathrm{m}) & \begin{array}{c}\text { Número de } \\ \text { furos }\end{array} \\ 1 & 390-400 & 27 \\ 2 & 380-390 & 78 \\ 3 & 370-380 & 96 \\ 4 & 360-370 & 110 \\ 5 & 350-360 & 128 \\ 6 & 340-350 & 136 \\ 7 & 330-340 & 142 \\ 8 & 320-330 & 142 \\ 9 & 310-320 & 142 \\ 10 & 300-310 & 141 \\ 11 & 290-300 & 139 \\ 12 & 280-290 & 133 \\ 13 & 270-280 & 123 \\ 14 & 260-270 & 113 \\ 15 & 250-260 & 101 \\ 16 & 240-250 & 87 \\ 17 & 230-240 & 73 \\ 18 & 220-230 & 46 \\ 19 & 210-220 & 30 \\ 20 & 200-210 & 19 \\ 21 & 190-200 & 8 \\ 22 & 180-190 & 8 \\ 23 & 170-180 & 7 \\ 24 & 160-170 & 5 \\ 25 & 150-160 & 3 \\ 26 & 140-150 & 1 \\ & & \end{array}$

\section{ANÁLISE GEOESTATÍSTICA dOS DADOS COMPOSTOS}

A análise geoestatística dos dados compostos foi realizada, com o objetivo de determinar a distribuição e variabilidade espaciais dos mesmos e, também, para definir o modelo de variograma que será utilizado para avaliação de reservas pela krigagem ordinária.

Para o estudo da distribuição espacial dos teores de cobre e ouro, compostos para as bancadas, utilizou-se das plantas de contorno de isoteores por bancada. Estas plantas foram obtidas a partir do arquivo de teores compostos, do qual foram extraídas as informações referentes à cada bancada e processadas em um conjunto de programas de computação para traçado automático de mapas de contorno, conforme procedimento descrito por Yamamoto (1986). A malha regular foi interpolada utilizandose do método IQD, com até 16 pontos vizinhos próximos, os quais foram localizados restringindo-se a busca para até quatro pontos por quadrante. As plantas de contorno de isoteores de cobre (expressos em \%) encontram-se nos desenhos das Figuras 5 a 15 e, para isoteores de ouro (expressos em ppm) nos desenhos das Figuras 16 a 26.

Nas Figuras 5 a 15 , observa-se que há uma tendência geral de aumento dos teores de cobre do topo para a base (bancada 360 para bancada 260). Nas três primeiras bancadas esta tendência de aumento é acompanhada do aumento da área de mineralização (Figuras 5, 6, e 7). Uma outra feição notável nestas plantas é a orientação da mineralização segundo a direção NE, compatível como modelo geológico da jazida. Pode-se, ainda observar que a partir da bancada 310 (Figura 10) e até a bancada 270 (Figura 14) passam a existir dois núcleos mineralizados (NE e SW) com teores superiores a $0,60 \%$ de cobre, desaparecendo praticamente na bancada 260 (Figura 15).

Nas plantas de isoteores de ouro por bancadas (Figuras 16 a 26), observa-se praticamente as mesmas feições indicadas para a variação de cobre. Porém, existe uma diferença significativa quanto à distribuição de ouro a partir da bancada 310 (Figura 21) em que o teor 


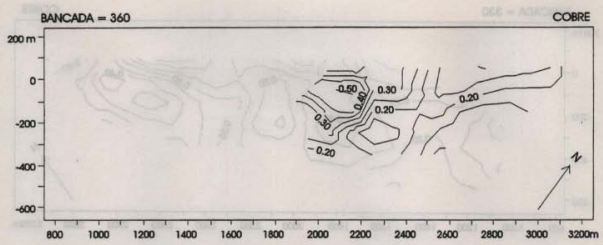

Figura 5 - Mapa de isoteores de cobre para a bancada 360.

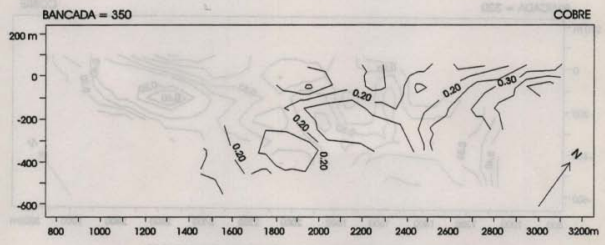

Figura 6 - Mapa de isoteores de cobre para a bancada 350.

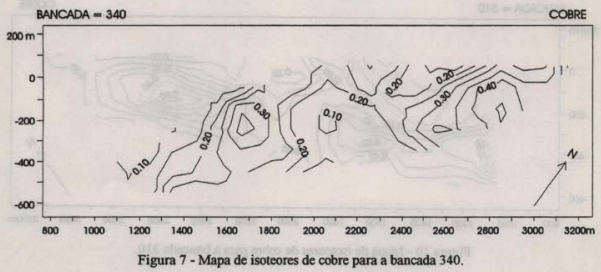




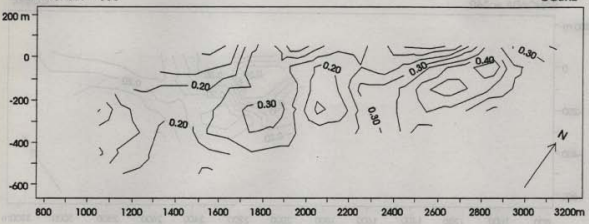

Figura 8 - Mapa de isoteores de cobre para a bancada 330.

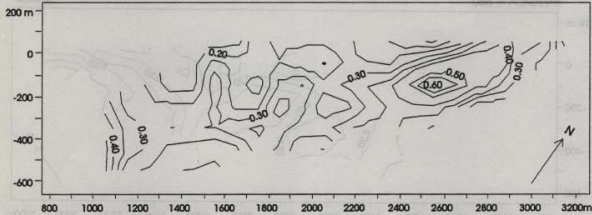

Figura 9 - Mapa de isoteores de cobre para a bancada 320.

BANCADA $=310$

COBRE

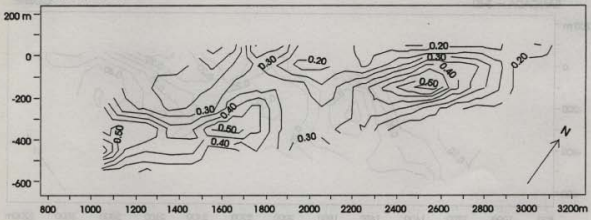

Figura 10 - Mapa de isoteores de cobre para a bancada 310. 


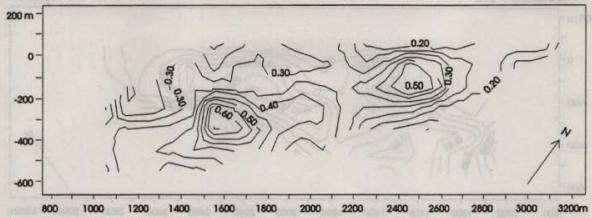

Figura 11 - Mapa de isoteores de cobre para a bancada 300.

$B A N C A D A=290$

COBRE

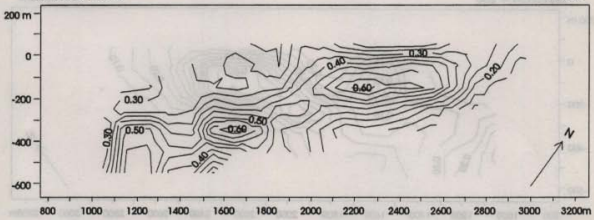

Figura 12 - Mapa de isoteores de cobre para a bancada 290.

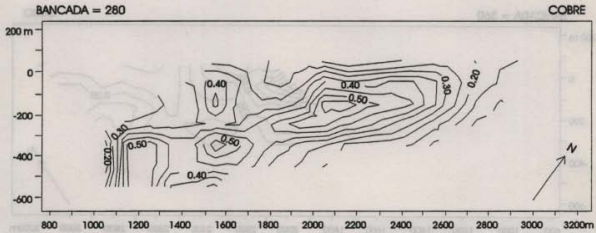

Figura 13 - Mapa de isoteores de cobre para a bancada 280. 


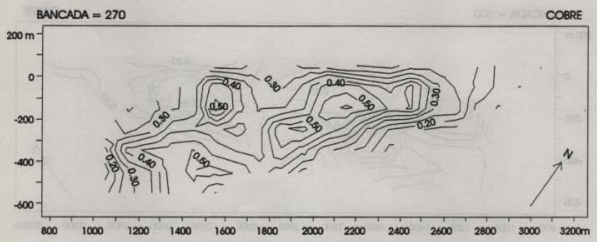

Figura 14 - Mapa de isovalores de cobre para a bancada 270.

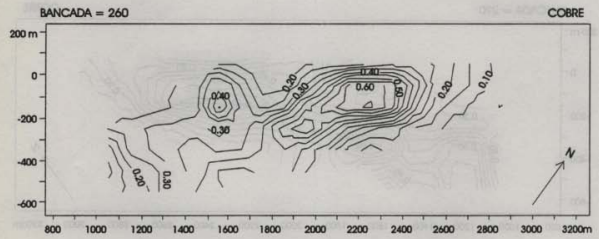

Figura 15 - Mapa de isoteores de cobre para a bancada 260.

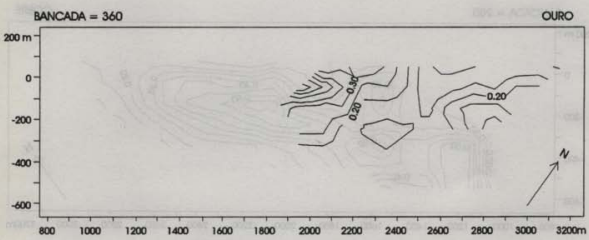

Figura 16 - Mapa de isoteores de ouro para a bancada 360. 


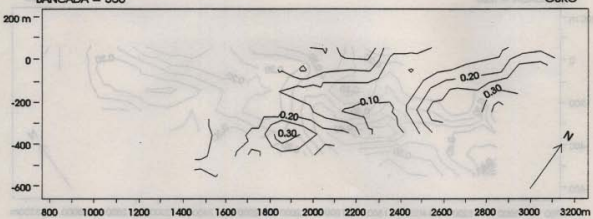

Figura 17 - Mapa de isoteores de ouro para a bancada 350.

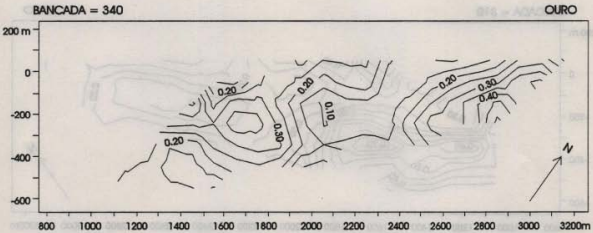

Figura 18 - Mapa de isoteores de ouro para a bancada 340.

BANCADA -330

OURO

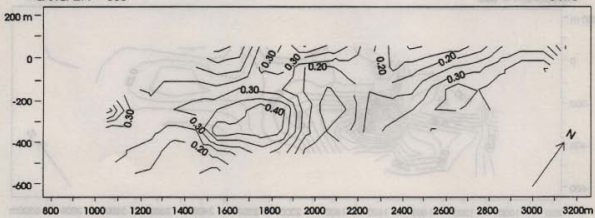

Figura 19 - Mapa de isoteores de ouro para a bancada 330. 


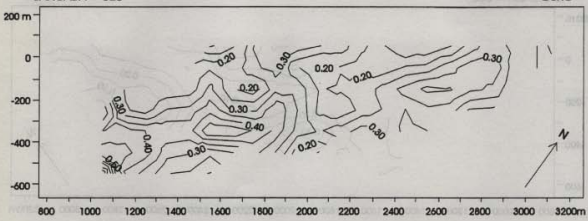

Figura 20 - Mapa de isoteores de ouro para a bancada 320.

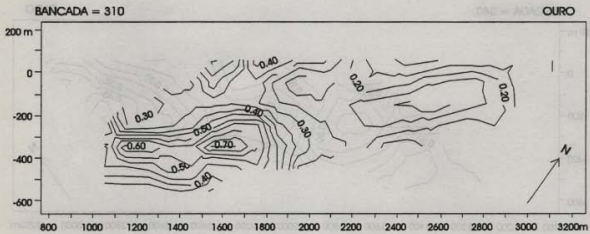

Figura 21 - Mapa de isoteores de ouro para a bancada 310.

BANCADA $=300$

OURO

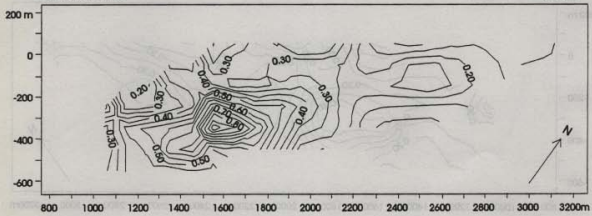

Figura 22 - Mapa de isoteores de ouro para bancada de 300. 


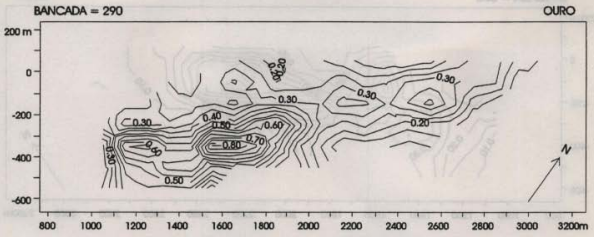

Figura 23 - Mapa de isoteores de ouro para a bancada 290.
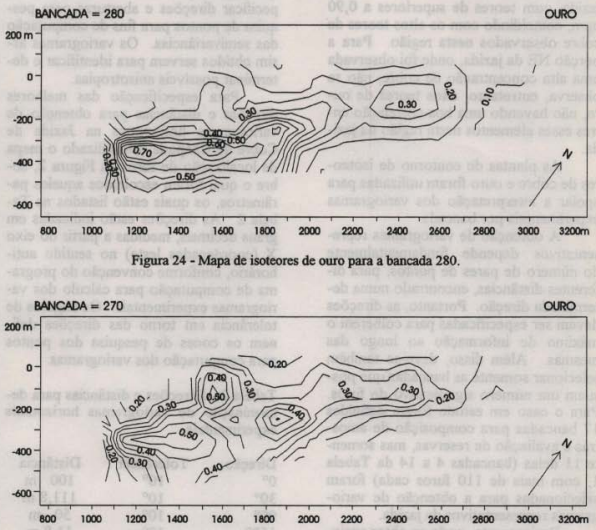

Figura 25 - Mapa de isoteores de ouro para a bancada 270. 


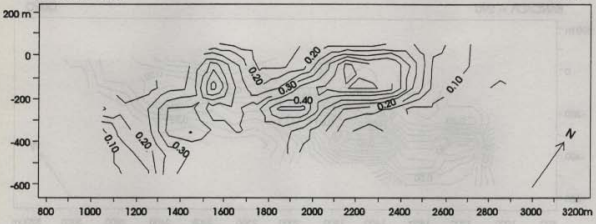

Figura 26 - Mapa de isoteores de ouro para a bancada 260.

de ouro concentra-se na porção SW da jazida, com teores de superiores a 0,90 ppm, coincidindo com os altos teores de cobre observados nesta região. Para a porção NE da jazida, onde foi observada uma alta concentração de cobre, não se observa, entretanto, altos teores de ouro, não havendo uma boa correlação entres esses elementos nesta região da jazida.

As plantas de contorno de isoteores de cobre e ouro foram utilizadas para apoiar a interpretação dos variogramas experimentais por bancada.

A obtenção de variogramas representativos depende fundamentalmente do número de pares de pontos, para diferentes distâncias, encontrado numa determinada direção. Portanto, as direções devem ser especificadas para colherem o máximo de informação ao longo das mesmas. Além disso, deve-se também selecionar somente as bancadas que possuam um número significativo de furos. Para o caso em estudo foram definidas 17 bancadas para composição de amostras e avaliação de reservas, mas somente 11 delas (bancadas 4 a 14 da Tabela 1 , com mais de 110 furos cada) foram selecionadas para a obtenção de variogramas representativos da jazida.

Basicamente, pode-se obter variogramas horizontais e verticais, sendo que para os primeiros deve-se ainda especificar direções e aberturas para pesquisa de pontos para fins de computação das semivariâncias. Os variogramas assim obtidos servem para identificar e determinar possíveis anisotropias.

Para especificação das melhores direções e distancias para obtenção de variogramas horizontais na Jazida de Cobre de Chapada, foi utilizado o mapa de localização de furos da Figura 2, sobre o qual foram escolhidos aqueles parâmetros, os quais estão listados na Tabela 2. As direções estão indicadas em graus decimais, medidas a partir do eixo $\mathrm{X}$ (coordenadas leste) no sentido antihorário, conforme convenção do programa de computação para cálculo dos variogramas experimentais. Os ângulos de tolerância em torno das direçôes definem os cones de pesquisa dos pontos para computação dos variogramas.

Tabela 2 - Direções e distâncias para determinação de variogramas horizontais experimentais.

$\begin{array}{lcc}\text { Direção } & \text { Tolerância } & \text { Distância } \\ 0^{\circ} & 10^{\circ} & 100 \mathrm{~m} \\ 30^{\circ} & 10^{\circ} & 111,8 \mathrm{~m} \\ 90^{\circ} & 10^{\circ} & 50 \mathrm{~m} \\ 150^{\circ} & 10^{\circ} & 11,8 \mathrm{~m}\end{array}$


Observe-se que as distâncias encontradas foram diferentes ao longo das direções, o que é justificável, visto que elas dependem da disposição e densidade dos furos de sondagem. A especificação de distâncias corretas, ao invés de uma distância única para todas as direções, por exemplo, $100 \mathrm{~m}$ para o caso em estudo, resulta num variograma estatisticamente mais significativo, em que as flutuaçōes pelas aproximaçōes de localização são atenuadas. Os critérios, portanto, para obtenção dos variogramas experimentais foram baseados exclusivamente na densidade de informações. Os critérios geológicos não foram utilizados pela ausência de correlação entre as litologias de furos vizinhos e, também, devido à composição de amostras dos furos de sondagem que ao promover a mistura de vários intervalos dificulta a identificação da litologia do intervalo composto.

Os variogramas horizontais foram obtidos individualmente para cada bancada e para cada direção, com o fim de identificar, bancada a bancada, possiveis diferenças na variabilidade de teores. Depois da análise e interpretação dos variogramas individuais para cada direção, estes foram compostos para um único variograma desta direção. Com relação aos variogramas verticais, devido ao grande número de furos, não foi adotado o procedimento de obtenção de variogramas individuais de furos, sendo calculado somente um variograma vertical composto por todos os furos, ou seja, acumulando-se todas as diferenças ao quadrado, para uma dada distância pesquisada em todos os furos.

Os variogramas experimentais por bancada foram compostos para a obtenção de variogramas médios representativos de todas as bancadas, com exceção da bancada 360 , cujos variogramas tanto para cobre como para ouro apresentaram-se com grandes dispersões e sem correlação com os demais variogra- mas. As rochas da bancada 360 por situarem-se próximas à superficie apresentam alteraçōes (oxidações no minério) que acabam por mascarar o padrão de distribuição dos teores de cobre e ouro, bem como a variabilidade espacial dos mesmos. Os pontos dos variogramas experimentais médios, para uma dada distância, foram obtidos acumulando-se todas as diferenças ao quadrado dos variogramas parciais e dividindo-se por duas vezes o número total de pares de pontos.

Os variogramas horizontais médios obtidos encontram-se nas Figuras 27 e 28 , respectivamente para cobre e ouro.

Da análise dos variogramas horizontais médios para cobre, verifica-se que na direção $30^{\circ}$, o variograma representa a variação de um fenômeno aproximadamente estacionário, enquanto para a direção $0^{\circ}$, dentro do campo geométrico estudado, verifica-se uma variação de um fenômeno estacionário. Para as outras direçōes não se pode tecer considerações a respeito da estacionaridade, devido ao pequeno número de distâncias de separação utilizado no cálculo desses variogramas.

Observando-se os variogramas horizontais médios para cobre, constata-se a existência de uma forte anisotropia geométrica, dada pelas amplitudes em torno de $400 \mathrm{~m}$ para as direçōes $0^{\circ} \mathrm{e}$ $30^{\circ}$ e em torno de $200 \mathrm{~m}$ para as direções $90^{\circ}$ e $150^{\circ}$, definindo um fator de anisotropia geométrica de aproximadamente dois.

Os variogramas horizontais médios para ouro, ao contrário dos mesmos para cobre, não são de fácil interpretação. Primeiro, porque os variogramas nas direções $0^{\circ}$ e $30^{\circ}$ representam variações de fenômenos tipicamente não estacionários e segundo, a anisotropia geométrica identificada para cobre não está tão claro nesse caso como estava para aquela variável. 


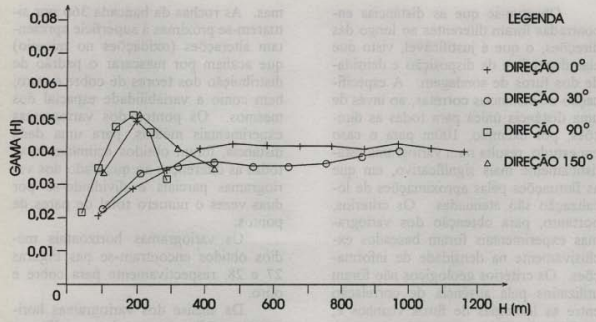

Figura 27 - Variogramas horizontais médios para cobre.

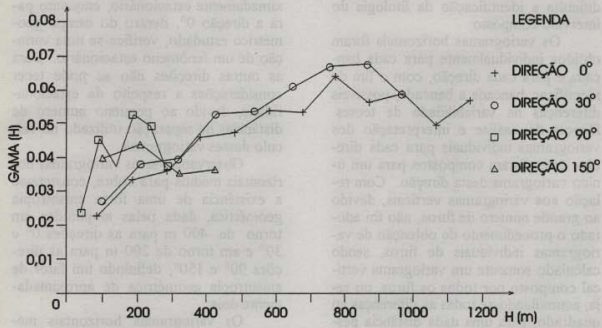

Figura 28 - Variogramas experimentais médios para ouro.

Para melhor entender estas variaçôes recorreu-se aos mapas de contorno de isoteores de cobre das bancadas, nos quais pode se verificar que exatamente entre as bancadas 310 a 270 , situa-se um núcleo mineralizado em ouro, com teo- res superiores à média da jazida. Os valores encontrados nos mapas foram confirmados, consultando os arquivos de dados compostos e originais. Verificouse também que muitos dos valores originais foram obtidos a partir da análise 
química de amostras já compostas por vários intervalos, os quais já haviam sido analisados para cobre. Este procedimento de amostragem pode talvez ter mascarado um nível mais rico em ouro dentro da jazida.

A deriva observada nos variogramas experimentais e confirmada pelo seu gráfico, localizada na porção $S W$ da jazida entre as bancadas 310 e 270 , origina-se provavelmente da falta de informações na região SW, ou seja, da complementação de trabalhos de pesquisa nesta região. Assim, tendo em vista a necessidade prática de obtenção de um modelo de variograma para ser utilizado na krigagem ordinária, recalculou-se os variogramas horizontais médios para ouro nas bancadas 320 a 350 (Fig. 29), como suporte à análise $\mathrm{e}$ interpretação dos variogramas horizontais médios da Figura 28.
Nos variogramas da Figura 28, pode-se observar agora claramente a existência de anisotropia geométrica um pouco menor que a verificada para cobre, dada pela amplitude nas direções $0^{\circ}$ e $30^{\circ} \mathrm{em}$ torno de $400 \mathrm{~m}$ e amplitude nas direções $90^{\circ}$ e $150^{\circ} \mathrm{em}$ torno de 250 m. Estas informaçōes podem ser transferidas para os variogramas horizontais médios de todas as bancadas para a obtenção de um modelo único para descrever a variabilidade espacial de ouro.

Com relação aos variogramas verticais, devido ao grande número de furos de sondagem dentro da área de interesse, decidiu-se calcular um único variograma vertical médio para cada variável.

Os variogramas verticais médios obtidos estão apresentados nas Figuras 30 e 31, para cobre e ouro, respectivamente. Nestas figuras pode-se observar que os variogramas verticais represen-

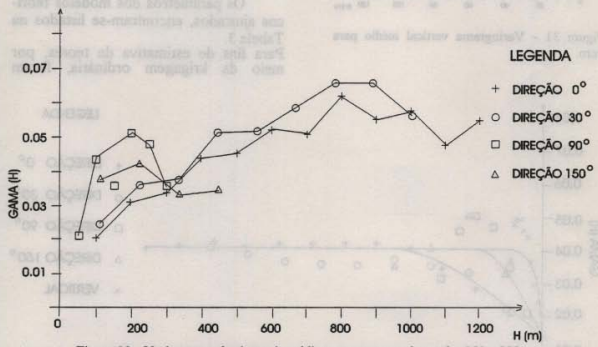

Figura 29 - Variogramas horizontais médios para ouro nas bancadas 350 a 320.

tam variações de fenômenos estacionários com tendência a estabilizar-se a partir de $80 \mathrm{~m}$ para cobre e em torno de
$100 \mathrm{~m}$ para ouro.

Os variogramas médios horizontais e verticais podem ser finalmente mo- 


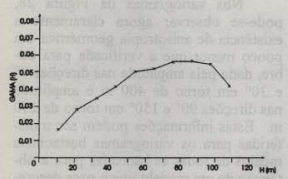

Figura 30 - Variograma vertical médio para cobre.

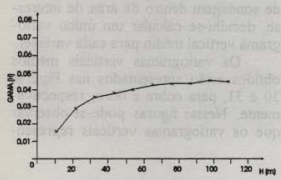

Figura 31 - Variograma vertical médio para ouro. delados pelo ajuste de uma equação matemática que descreva a variabilidade espacial em funçăo da distância e orientação.

Dentre os modelos teóricos disponiveis foi escolhido o modelo esférico, que deve melhor se ajustar aos dados obtidos. O ajuste de modelos teóricos aos variogramas experimentais foi feito interativamente por tentativa e erro, introduzindo-se os parâmetros na equação (efeito pepita, variância a priori e amplitude) e verificando-se visualmente a resposta obtida com relação aos pontos experimentais. Se o ajuste foi satisfatório o modelo é adotado, caso contrário o procedimento é repetido até que o modelo ajustado seja considerado satisfatório. Os modelos de variogramas teóricos assim encontrados foram desenhados juntamente com os respectivos pontos experimentais e encontram-se representados nos gráficos das Figuras 32 e 33 .

Os parâmetros dos modelos teóricos ajustados, encontram-se listados na Tabela 3.

Para fins de estimativa de teores, por meio da krigagem ordinária, foram

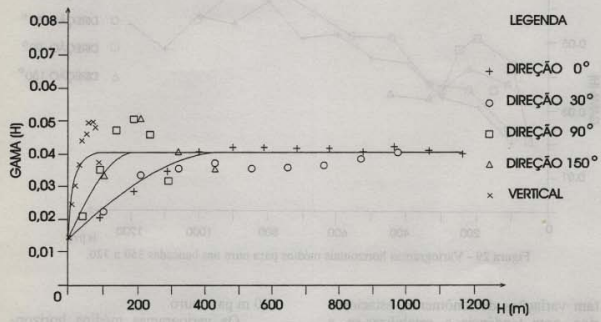

Figura 32 - Modelos de variogramas teóricos para cobre. 


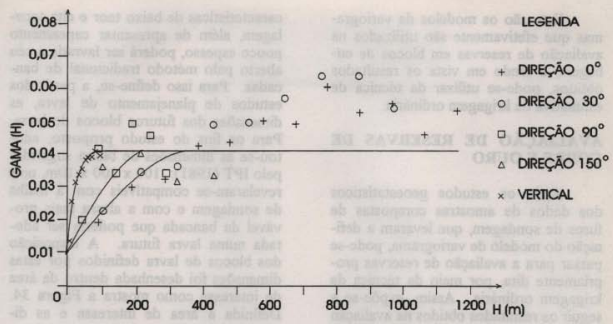

Figura 33 - Modelos de variogramas teóricos para ouro.

utilizados os modelos das equações (1) e (2), para cobre e ouro, respectivamente.

$\gamma(h)=0,015+0,022\left[1,5 \frac{h}{450}-0,\left\{\left(\frac{h}{450}\right)^{3}\right] p / h=450 m\right.$

$\gamma(\mathrm{h})=0,042 \mathrm{p} / \mathrm{h}>450 \mathrm{~m}$

$\gamma(\mathrm{h})=0.010+0,03 \pi\left[1.5 \frac{\mathrm{h}}{400}-0 .\left(\frac{\mathrm{h}}{400}\right)^{3}\right] \mathrm{p} / \mathrm{h}=400 \mathrm{~m}$

$\gamma(\mathrm{h})=0,043 \mathrm{p} / \mathrm{h}>400 \mathrm{~m}$

Tabela 3 - Parâmetros dos modelos teóricos de variogramas.

Variável Efeito Patamar Alcances

0.: 450

Cobre $\quad 0,015 \% \%^{2} \quad 0,042 \%^{2} \quad 90^{\circ}: 200$

VER: 100

$90^{\circ}: 250$

VER: 100
As amplitudes obtidas para os dois casos foram inferiores à provável deriva, detectada a partir de $500 \mathrm{~m}$, para os teores de ouro. Portanto, os modelos obtidos são perfeitamente válidos para estimativa de teores, por meio da krigagem, limitando as amostras até a amplitude ou, no máximo, em casos excepcionais (blocos na borda da área de interesse) até $500 \mathrm{~m}$.

Para compensar os efeitos da anisotropia geométrica existente para ambos os casos, introduz-se as razões de anisotropia geométrica horizontal e vertical para correção das distâncias de acordo com a direção de anisotropia. As razões de anisotropia obtidas para o caso em estudo estão apresentadas na Tabela 4 .

Tabela 4 - Razões de anisotropia horizontal e vertical.

\begin{tabular}{lcc} 
& \multicolumn{2}{c}{ Razōes de anisotropia } \\
Variável & Horizontal & Vertical \\
Cobre & 2,25 & 4,50 \\
Ouro & 1,60 & 4,00
\end{tabular}


Este são os modelos de variogramas que efetivamente são utilizados na avaliação de reservas em blocos de cubagem, e tendo em vista os resultados obtidos, pode-se utilizar da técnica de estimativa da krigagem ordinária.

\section{AVALLAÇão DE RESERVAS DE COBRE E OURO}

Após os estudos geoestatísticos dos dados de amostras compostas de furos de sondagem, que levaram a definição do modelo de variograma, pode-se passar para a avaliação de reservas propriamente dita, por meio da técnica da krigagem ordinária. Assim, expõe-se a seguir os resultados obtidos na avaliação de reservas de cobre e ouro da Jazida de Cobre de Chapada. Para fins de avaliação de reservas, deve-se antes definir as dimensões dos blocos de cubagem ou de lavra, bem como as condiçōes em que tais blocos foram avaliados.

As dimensões dos futuros blocos de lavra devem ser definidas em função do método de lavra a ser empregado. A jazida de cobre de Chapada, pelas suas características de baixo teor e alta tonelagem, além de apresentar capeamento pouco espesso, poderá ser lavrada a céu aberto pelo método tradicional de bancadas. Para isso define-se, a partir dos estudos de planejamento de lavra, as dimensões dos futuros blocos de lavra. Para os fins do estudo proposto, adotou-se as dimensões de bloco sugeridas pelo IPT (1981): $100 \times 100 \times 10 \mathrm{~m}$, pois revelaram-se compativeis com a malha de sondagem e com a altura mais provável da bancada que poderia ser adotada numa lavra futura. A disposição dos blocos de lavra definidos por estas dimensões foi desenhada dentro da área de interesse como mostra a Figura 34. Definida a área de interesse $\mathrm{e}$ as dimensōes dos blocos de lavra, estes podem ser numerados seqüencialmente e localizados em termos de linhas, colunas e níveis de um arranjo tridimensional de blocos, como mostra o modelo tridimensional de blocos para a jazida de Chapada (Fig. 35).

$\mathrm{Se}$ as colunas, linhas e niveis forem identificados pelos indices $\mathrm{J}, \mathrm{I}$ e $\mathrm{K}$, respectivamente, o número do bloco po-

ESCALA

- $100200300400500 \mathrm{~m}$

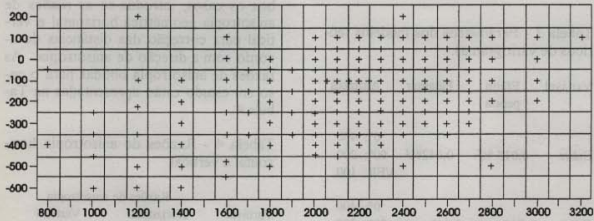

Figura 34 - Disposição dos blocos de lavra, dentro da área de interesse. 


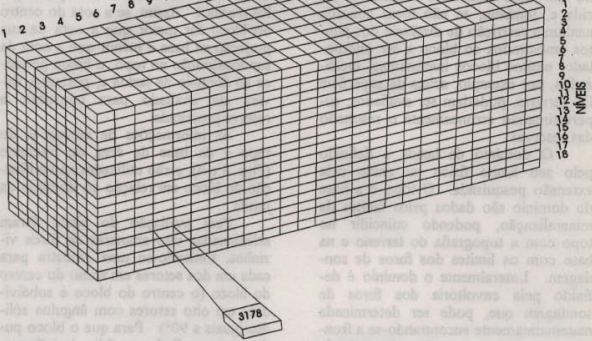

Figura 35 - Modelo tridimensional de blocos para a Jazida de Cobre de Chapada, com evidência para o bloco 3178.

de ser obtido pela seguinte relação:

$\mathrm{NB}=\mathrm{I}+\mathrm{NY} \cdot(\mathrm{J}-1)+\mathrm{NX} \cdot \mathrm{NY} \cdot(\mathrm{K}-1)$

onde: NB é o número do bloco;

NX, NY e NZ são respectivamente 0 número de blocos nas direções de coordenadas $\mathrm{X}, \mathrm{Y}$ e Z.

Por outro lado, dado um ponto em termos de suas coordenadas $(x, y, z)$ é possivel localizar o bloco, calculando-se os indices $\mathrm{I}, \mathrm{J} \mathrm{e} \mathrm{K}$, como segue:

$J=\operatorname{TRUNC}[(\mathrm{x}-\mathrm{xmin}) / \mathrm{dx}]+1$

$I=\operatorname{TRUNC}[(y-y \min ) / d y]+1$

$\mathrm{K}=\mathrm{TRUNC}[(\mathrm{z}-\mathrm{zmin}) / \mathrm{dz}]+1$

onde: $\mathrm{dx}$, dy e dz são, respectivamente, as dimensões dos blocos nas direções de coordenadas X, Y e Z; xmin, ymin e zmax são as coordenadas da origem do sistema de numeração de blocos;

TRUNC representa um operador Pascal que indica que somente a parte inteira do resultado entre colchetes será considerada.

Definido o modelo tridimensional de blocos para o caso em estudo, há ainda a necessidade de saber quais os blocos que efetivamente poderão ser avaliados em função da disponibilidade de informaçōes nas três dimensões da jazida. Pode-se definir a região que engloba todos os blocos da área de interesse como o dominio da jazida que tem também um sentido matemático que é o domínio dentro do qual são válidas as interpolações da variável de interesse, usando as informaçōes disponiveis. Em outras palavras, qualquer procedimento de interpolação só é válido dentro do 
domínio dos dados, caso contrário o procedimento é de extrapolação, sobre o qual se tem pouco ou nenhum controle. Se não fosse definido o domínio da jazida e, também, se não fosse aplicada nenhuma restrição de distância dos pontos amostrados ao bloco a ser interpolado, muitos blocos inexistentes, localizados, por exemplo, acima da superficie Do terreno, poderiam ser avaliados, superestimando erroneamente o resultado das reservas.

O dominio da jazida é definido pelo seu limite físico ou então pela extensão pesquisada. $O$ topo e a base do domínio são dados pelos limites da mineralização, podendo coincidir no topo com a topografia do terreno e na base com os limites dos furos de sondagem. Lateralmente o dominio é definido pela envoltória dos furos de sondagem que, pode ser determinada matematicamente encontrando-se a fronteira convexa, ou então, determinada manualmente sobre o conjunto dos furos de sondagem pelo geólogo responsável pela pesquisa, que procurará definir este limite com seus conhecimentos da extensão da mineralização. A fronteira convexa, segundo Eddy (1977), é definida como sendo o polígono de área mínima que engloba o conjunto dos furos de sondagem da área de interesse. Para o caso em estudo, adotou-se a envoltória dos furos de sondagem definida pela fronteira convexa dos mesmos. Agora para se saber se um determinado bloco pertence ou não à envoltória dos furos, pode-se aplicar o algoritmo de Hall (1975), que se baseia na soma de ângulos formados entre 0 centro do bloco e todos os vértices do polígono. Se esta soma for $\pm 360^{\circ} \circ$ bloco está dentro, caso contrário (soma igual $0^{\circ}$ ) o bloco está fora.

Se o bloco estiver dentro da envoltória do conjunto de furos de sondagem, deve-se testar ainda se o mesmo está contido entre as superficies do topo e base da jazida. A superficie do topo é definida pelas cotas das bocas dos furos de sondagem e a superficie da base pelas cotas das profundidades alcançadas pelos mesmos. Assim, se a cota do centro do bloco for maior que a cota da sua projeção na base e menor que a cota da sua localizaçăo no topo, o bloco pertence ao domínio da jazida e, portanto, deverá ser avaliado para constituir a reserva procurada.

As informações de elevações do topo e da base da área de interesse (Figs. 3 e 4), serão utilizadas na verificação do bloco em relação ao domínio da jazida.

Para avaliação do bloco foram selecionadas oito amostras de furos vizinhos, tomando-se uma amostra para cada um dos setores em torno do centro do bloco (o centro do bloco é subdividido em oito setores com ângulos sólidos iguais a $90^{\circ}$ ). Para que o bloco pudesse ser avaliado, na falta de informações suficientes, foi fixado o minimo de quatro amostras de furos vizinhos.

A discretização do bloco, para fins da krigagem ordinária de bloco, foi feita com 16 sub-blocos, sendo quatro na direção $\mathrm{X}$, quatro na direção $\mathrm{Y}$ e um na direção $Z$, que resultou em sub-blocos de $25 \times 25 \times 10 \mathrm{~m}$, razoável para a densidade de amostragem e compativel para a altura das bancadas.

Considerando-se as condiçōes anteriores, verificou-se que do total de 4.050 blocos do modelo tridimensional da jazida, 1.941 não pertenciam ao dominio da jazida e 2.109 pertenciam ao domínio da jazida, dos quais 1.896 foram avaliados para teores de cobre e ouro e 213 não avaliados por não apresentarem amostras suficientes para isso.

Dessa forma, calculou-se as reservas geológicas de cobre e ouro (metais contidos), para teores de corte simulados iguais a $0,20,0,25$ e 0,30 , respectivamente em \% para cobre e ppm para ouro, conforme os resultados reproduzi- 
dos na Tabela 5.

Tabela 5 - Reservas geológicas de cobre e ouro (metais contidos em ton) da Jazida de Cobre de Chapada (teores médios em \% para cobre e ppm para ouro).

\begin{tabular}{|c|c|c|c|}
\hline Variável & $\begin{array}{c}\text { Teor de } \\
\text { corte }\end{array}$ & $\begin{array}{l}\text { Reserva } \\
\text { geológica }\end{array}$ & $\begin{array}{l}\text { Teor } \\
\text { médio }\end{array}$ \\
\hline \multirow[t]{3}{*}{ Cobre } & 0,20 & 1.004 & 0,34 \\
\hline & 0,25 & 834 & 0,38 \\
\hline & 0,30 & 666 & 0,42 \\
\hline \multirow[t]{3}{*}{ Ouro } & 0,20 & 90,97 & 0,36 \\
\hline & 0,25 & 77,15 & 0,40 \\
\hline & 0,30 & 64,85 & 0,44 \\
\hline
\end{tabular}

\section{CONSIDERAÇŌES FINAIS}

Foram apresentados os resultados do estudo geoestatístico da Jazida de Cobre de Chapada, visando a determinação dos modelos de variogramas para avaliação de reservas por meio da krigagem ordinária.

A composição de amostras de furos de sondagem para a altura das bancadas, foi efetuada com o objetivo de regularizar os suportes para a análise variográfica.

Os variogramas horizontais e verticais revelaram a existência de uma forte anisotropia geométrica, cujo eixo tem direção $0-30^{\circ}$. A interpretação dos variogramas médios, apoiada nos mapas de isoteores por bancada, resultou na escolha dos modelos teóricos para ajuste aos dados experimentais.

Finalmente, recomenda-se a realização da análise geoestatistica para que - variograma do depósito seja representativo da variabilidade espacial e, por isso, para que a avaliação de reservas, por meio da krigagem ordinária, seja significativa, pois para a krigagem qualquer que seja o modelo de variograma introduzido, haverá sempre uma resposta, cuja consistência vai depender da representatividade e validade do mo- delo.

\section{AGRADECIMENTOS}

O autor expressa os seus mais sinceros agradecimentos a pessoas e instituiçōes que colaboraram para a realização da sua tese de doutoramento, da qual foi derivado este trabalho. Aos Profs. Drs. Gilberto Amaral e Jorge S. Bettencourt pela orientação dada. A ELUMA S.A., por meio de seu diretor Dr. Julio C.Senna, que autorizou a utilização dos dados da Jazida de Cobre de Chapada e permitiu a publicação deste trabalho. Ao Instituto de Geociências da Universidade de São Paulo, que proporcionou todas as condições para realização da tese de doutoramento.

\section{REFERÊNCIAS BIBLIOGRÁFICAS}

EDDY, W.F. (1977) A new convex hull algorithm for planar sets. ACM Transaction on Mathematical Software, v.3, n.4, p.398-403.

HALL, J.K. (1975) PTLOC-A FORTRAN subroutine for determining the position of a point relative to a closed boundary. Mathematical Geology, v. 7, n.1, p.75-79.

HANDLEY, G.A.; LEWIS, R.W.; WILSON, I. (1987) The collection and management of ore reserve estimation data. In: RESOURCES AND RESERVES SYMPOSIUM, Sydney, 1987. Proceedings. Sydney, The Australasian Institute of Mining and Metallurgy. p. 27-30.

INSTITUTO DE PESQUISAS TECNOLÓGICAS DO ESTADO DE SÃO PAULO (1980a) Estruturas da área mineralizada de Chapada, GO. São Paulo, IPT. 7p. (Relatório IPT, 14.181).

INSTITUTO DE PESQUISAS TECNOLÓGICAS DO ESTADO DE SÃO PAULO (1980b) Estudo preliminar do comportamento estru- 
tural do corpo mineralizado da jazida de Chapada e correlação da mineralização com os tipos petrográficos. São Paulo, IPT. 6p. (Relatório IPT, 14.063).

INSTITUTO DE PESQUISAS TECNOLÓGICAS DO ESTADO DE SÃO PAULO (1981) Cálculo de reservas mineráveis de cobre e ouro da Jazida de Chapada, com dados de 156 sondagens. São Paulo, IPT. 15p. (Relatório IPT, 15.985).

KUYUMJIAN, R.M. (1990) As zonas de alteração associadas ao depósito de cobre-ouro de Chapada, Goiás, Brasil. In: CONGRESSO BRASILEIRO DE GEOLOGIA, 36. Natal, 1990. Anais. Natal, SBG, v.3. p. 1172-1178.

RICHARDSON, S.V.; KESLER, S.E.; ESSENE, E.J. (1986) Origin and geochemistry of the Chapada $\mathrm{Cu}-\mathrm{Au}$ Deposit, Goiás, Brasil: a metamorphosed wall-rock porphyry copper deposit. Economic Geology, v. 81, p.1884-1898.

SILVA, J.A. (1979) Relatório final de pesquisa. São Paulo, Mineração Serras do Leste-MINERALESTE. 8 vols.

SILVA, J.A; SÁ, J.A.G. (1988) Jazida de Cobre de Chapada, Mara Rosa, Goiás. In: SCHOBBENHAUS, C.; COELHO, C.E.S. (coords.). Principais depósitos minerais do Brasil. Brasilia, DNPM/ CVRD. Vol. III, p. 55-60.

YAMAMOTO, J.K. (1986) Representaçôes gráficas espaciais em geologia: aplicações no Complexo Alcalino de Anitápolis. São Paulo. 167p. (Dissertação de Mestrado - Instituto de Geociências/USP).

YAMAMOTO, J.K. (1991) Comparação de métodos computacionais para avaliaçăo de reservas: um estudo de caso na Jazida de Cobre de Chapada, GO. 175p. (Tese de Doutoramento - Instituto de Geociências/USP).

J.K.Yamamoto - Instituto de Geociências, Universidade de São Paulo, Caixa Postal 11.348, CEP 05422-970, São Paulo, SP, Brasil. 